METALLURGY AND FOUNDRY ENGINEERING - Vol. 38, 2012, No. 2

http://dx.doi.org/10.7494/mafe.2012.38.2.171

Jadwiga Kamińska*, Angelika Kmita*, Joanna Kolczyk*, Paulina Malatyńska*

\title{
STRENGTH PARAMETERS AND A MECHANICAL RECLAMATION TOGETHER WITH THE MANAGEMENT OF ITS BY-PRODUCTS
}

\section{INTRODUCTION}

A reclamation of spent foundry and core sands in the reclamation processes and their reuse as a substitute of fresh sands in newly prepared moulding and core sands is a complex problem, due to its technological and ecological aspects [4].

The reclamation of spent foundry sands is a process applied for a recovery of sands grains. Sand grains of a majority of moulding sands constitute high-silica sand. In technological processes of the moulding sands preparation the binding agents joining sand grains are applied. They make impossible reusing of moulding sands components in the successive cycle of casting productions. Thus, moulding sands produced with addition of such binders are useless in the successive cycles. The basic components of moulding sands are sand grains, constituting more than $90 \%$ of their composition. Sand grains are not changed in the casting production process and after the reclamation can be reused in successive cycles of the technological process. The reclamation of sand grains is based on cleaning grain surfaces from solidified binders and on removal cleaning products from the grain structure [5-10].

The technology of moulding sands with resins containing furfuryl alcohol (furan) is applied for making middle and large castings at small and middle lot productions as the so-called technology of loose self-setting sands, chemically hardened in an ambient temperature [2].

* M.Sc.: AGH University of Science and Technology, Faculty of Foundry Engineering, Krakow, Poland; e-mail: kaminska@agh.edu.pl 


\section{THE SCOPE AND INVESTIGATION METHODOLOGY}

Investigations were divided into the following stages:

\section{1 stage:}

Preparation of the moulding sand with furan resin with sand grains of fresh high-silica sand of the following composition:

- high-silica sand 100 parts by mass,

- furan resin U404 in various amounts $(0.8 ; 1.0 ; 1.2$ parts by mass $)$,

- hardener 100T3 in various amounts $(0.3 ; 0.5 ; 0.7$ parts by mass).

\section{2 stage:}

Making shaped samples for testing the bending strength $R_{g}^{u}$ and tensile strength $R_{m}^{u}$.

\section{3 stage:}

Performing the secondary reclamation of the moulding sand in the testing apparatus AT-2, at the impact-abrasive element rotational speed being $460 \mathrm{rot} / \mathrm{min}$. The reclamation time was successively: 5, 10, 15 and 20 minutes.

\section{4 stage:}

Blowing away the reclaim in the cascade classifier in order to remove dust fractions from the reclaimed material, air velocity: $1 \mathrm{~m} / \mathrm{s}$, time: 4 minutes.

\section{5 stage:}

Preliminary granulation tests of after reclamation dusts originated from the moulding sand with furan resin - in the experimental device.

\section{OBTAINED RESULTS}

\subsection{Strength tests of the moulding sand with furan resin}

A comparison - in what way the moulding sand strength is changing in dependence on the hardener content varying from 0.3 to 0.7 parts by weight, at a constant resin addition was performed.

On the basis of the diagram (Fig. 1), it can be noticed that with an increase of the hardener content the strength of shaped elements made of this moulding sand is also increasing. Moulding sands with the hardener addition in amounts of 0.5 and 0.7 parts by weight, achieve good strength already after 2 hours of hardening. The binding rate of these samples is high and the obtained strength is higher than of moulding sands containing 0.3 parts by weight, after 24 hours.

The successive stage of investigations was testing an influence of adding resin on the moulding sand strength (Fig. 2). Resin additions varied from 0.8 to 1.2 parts by mass, while the hardener addition was constant and equal 0.5 parts by mass. 


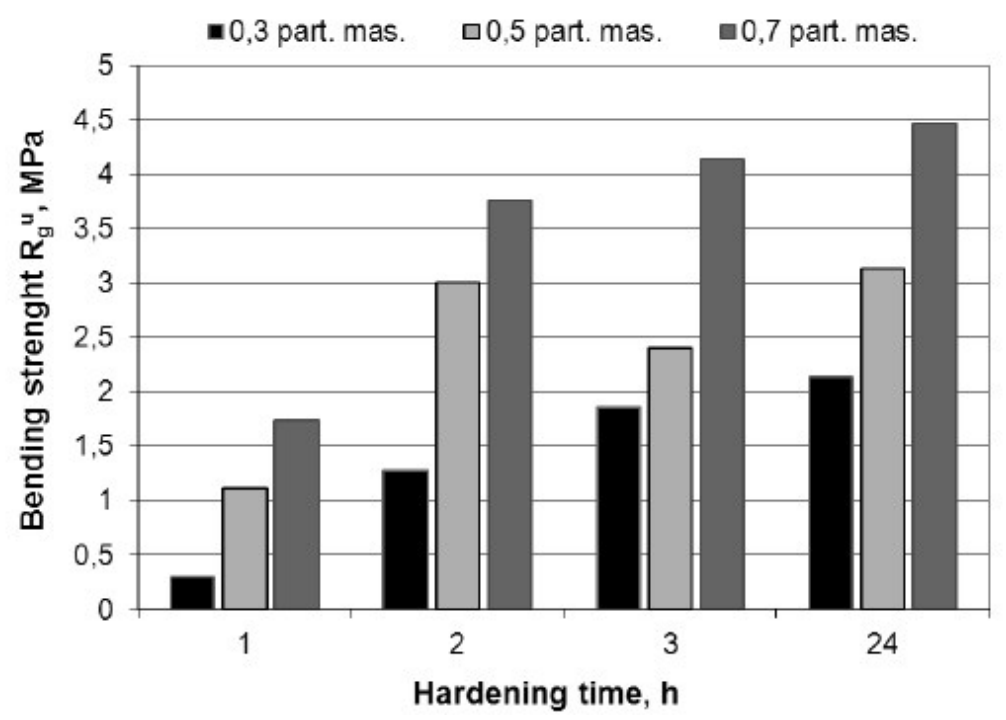

Fig. 1. Comparison of bending strength of SMS, containing 1.0 parts mas weight furan resin with different amount of hardener

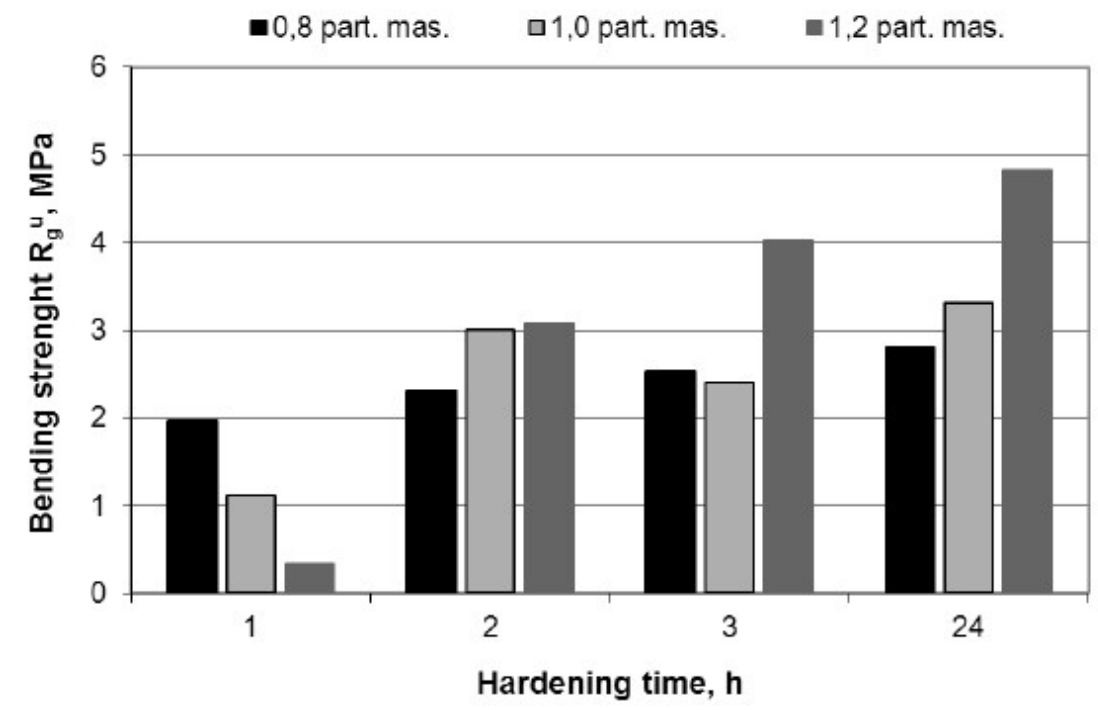

Fig. 2. Comparison of bending strength of SMS, containing 0.5 parts mas hardener with different amount of furan resin

Resin additions in amounts of 0.8 and 1.0 parts by mass, allow to obtain similar strength values after 24 hours of hardening. An addition of 1.2 parts by mass of resin causes the strength increase, already after 2 hours, to the level which the remaining compositions obtain barely after 24 hours of hardening. 


\subsection{Sieve analysis and ignition loss of the reclaimed material}

The sieve analysis carried out for not de-dusted sands after reclamation, indicates clearly that together with an increased reclamation time the amount of dust fractions increases. This indicates that elementary operations: rubbing, grinding and crushing occur in the reclaimer, causing a systematic removal of spent binders coatings from sand grains.

Changes of the average grain diameter $\mathrm{dL}$ of spent foundry sand, subjected to the reclamation treatment in the testing device AT-2, are shown in Figure 3. When comparing these data, one can notice that the average grain diameter $\mathrm{dL}$ decreases with the reclamation time prolongation.

When the reclamation is done at the rotor rotational speed of $460 \mathrm{rot} / \mathrm{min}$ a decrease of average diameter $d L$ is slight, moreover it can be the most visibly noticed at position 1 of the reclaimer, it means when $\alpha=0^{\circ}$. Positions $2\left(\alpha=3,5^{\circ}\right)$ and $3\left(\alpha=6^{\circ}\right)$ provide smaller reclamation effects.

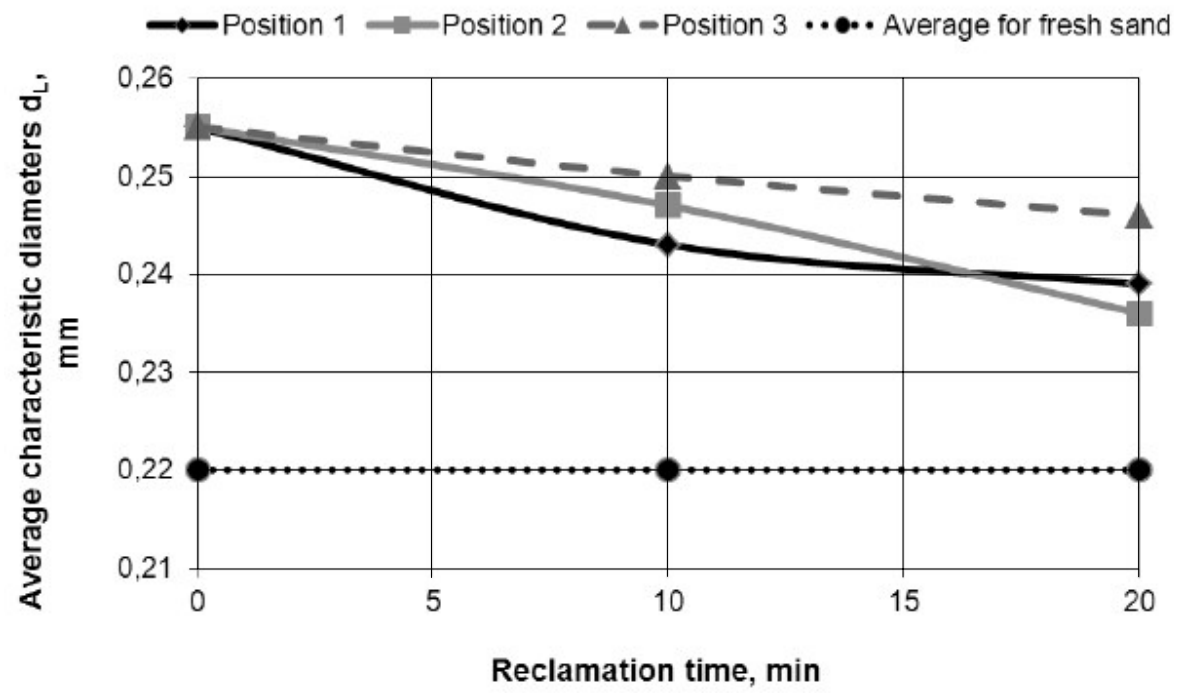

Fig. 3. Change of the average characteristic diameters $d_{L}$ as a function of the reclamation time

The influence of the mechanical reclamation time in the testing device AT- 2 on the theoretical specific surface $S_{t}$, is presented in Figure 4. It results from the diagram that, the longer reclamation time the larger theoretical surface of grains. The largest growth is observed when the device vessel is in position 3 , it means when its inclination angle $\alpha=6^{\circ}$ (app. 8\%). The growth of the theoretical specific surface results from decreasing of the average diameter of the reclaimed grains set, during the reclamation treatment.

The ignition loss value provides information on the spent binder amount remaining on sands grains after the reclamation process. 


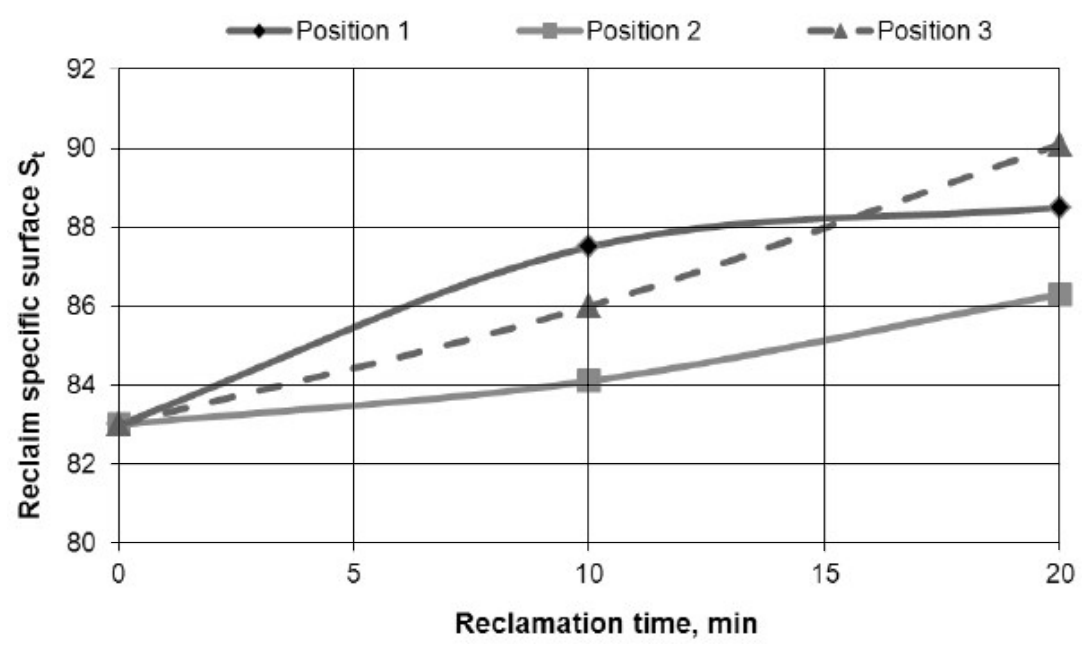

Fig. 4. Change of the reclaim specific surface $S_{t}$ as a function of the reclamation time

The analysis of Figure 5 indicates that ignition losses of the reclaimed material decrease with the reclamation time prolongation. This shows that coatings of binding material are removed more precisely. The average decrease of ignition losses with time equals approximately $28 \%$, while the highest, being approximately $45 \%$ (after 20 minutes) is obtained in position 1 , which means the device inclination angle $\alpha=6^{\circ}$.

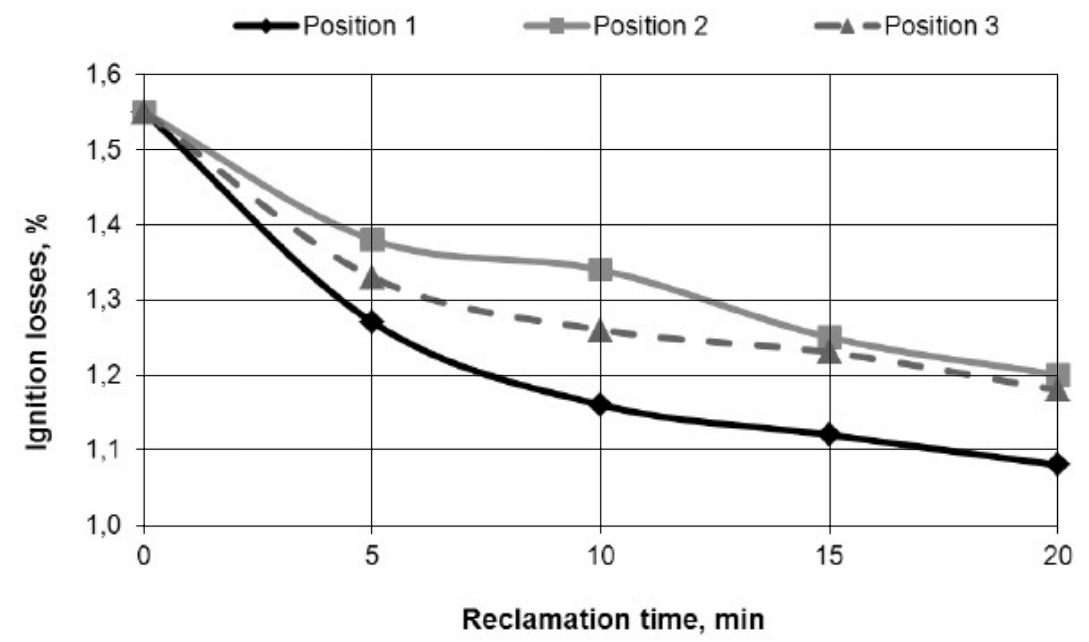

Fig. 5. Ignition losses of reclaimed sands as a function of the reclamation time

\subsection{Results of granulation attempts of after the reclamation dusts}

A mixture of dusts containing 50 mass \% of dusts from a moulding sand with bentonite and 50 mass $\%$ of dusts after the reclamation of a furan moulding sand was subjected to the 
granulation process in the prototype bowl granulator [11, 12]. The granulating bowl was rotating, in turn with rotational speeds of 10 and $20 \mathrm{rot} / \mathrm{min}$, at the inclination angle being $45^{\circ}$. The wetted material was agglomerating and granules of diameters from $3 \mathrm{~mm}$ to $60 \mathrm{~mm}$ were formed.

The example of dimensions of the obtained granules is shown in Figure 6.

a)

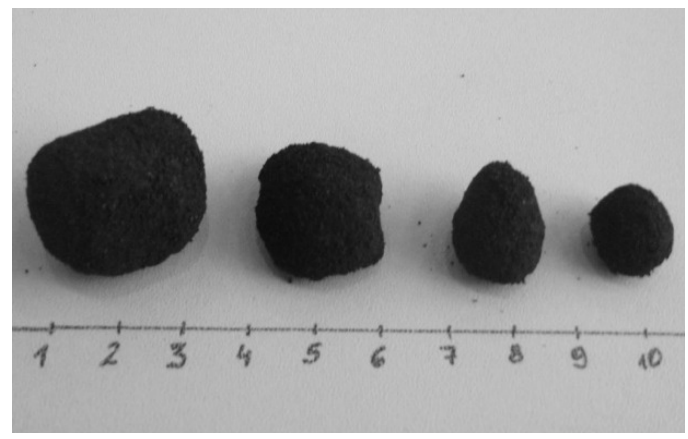

b)

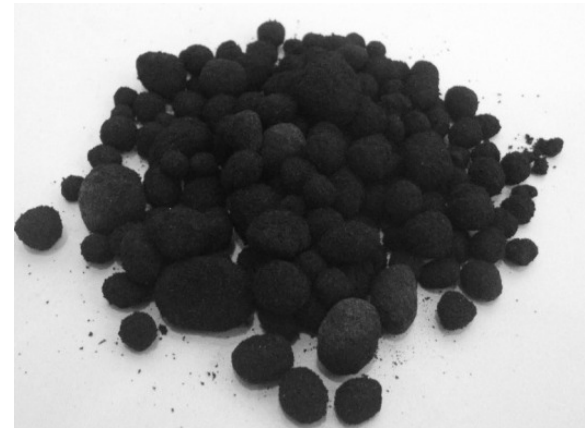

Fig. 6. Granulate fractions, granulator rotational speed - $10 \mathrm{rpm}$, angle of inclination $-40^{\circ}$, scale given in centimeters

The dependence of the shatter test resistance of granules, at a rotational speed of the granulator bowl being $10 \mathrm{rot} / \mathrm{min}$, on the seasoning time, is presented in Figure 7 . In case of samples tested after one shatter the constant strength decrease is observed with the seasoning time increase. The lowest strength is obtained after 10 days of seasoning. In case of strength obtained after 3 shatters, up to the fifth day the strength decrease with the increase of the seasoning time is observed, however after exceeding this time the granules strength increases.

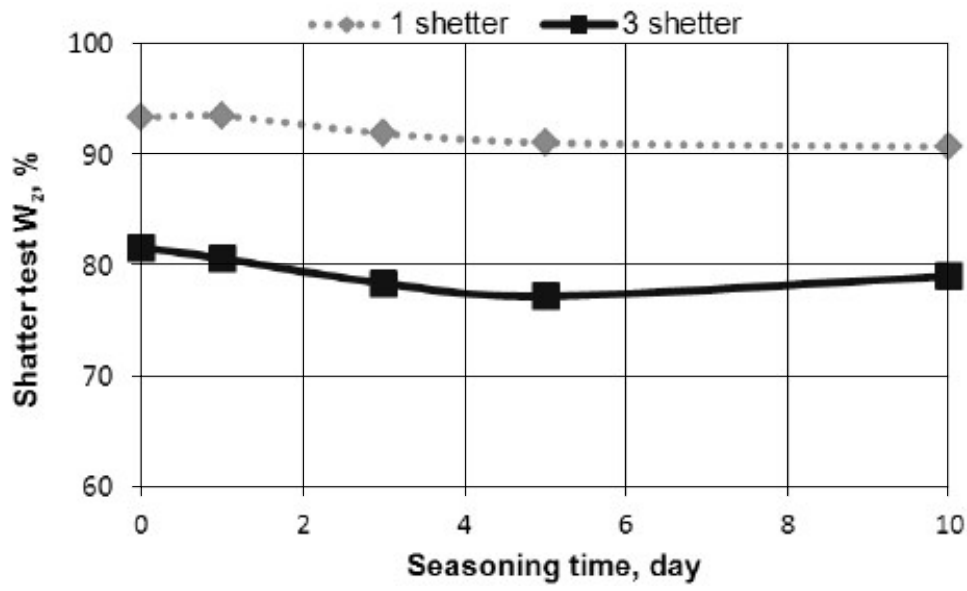

Fig. 7. Dependence of shatter tests value on the granules seasoning time, rotational speed of the granulator disk: $10 \mathrm{rpm}$, angle of inclination of the disk: $45^{\circ}$ 
The dependence of the shatter test resistance on the seasoning time, at a rotational speed of $20 \mathrm{rot} / \mathrm{min}$, is presented in Figure 8. The fresh granular material and after 10 days of seasoning after the first shatter obtains practically $100 \%$ strength. After being shattered on the steel plate granules are not breaking up. The lowest strength have granules after 5 days of seasoning. The similar waveform has the strength curve of the tested samples after 3 shatters, which obtain the highest strength after 3 days of seasoning.

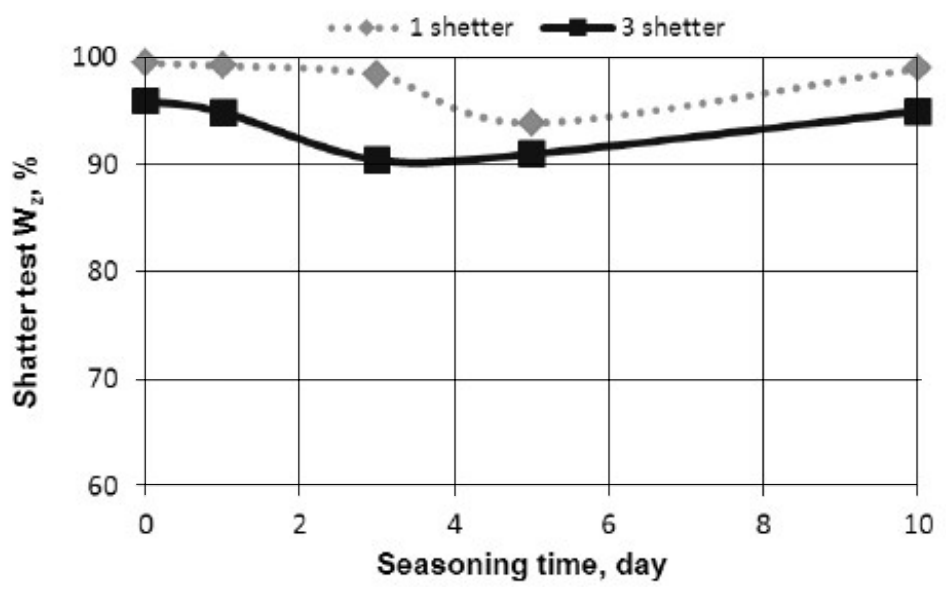

Fig. 8. Dependence of shatter tests value on the granules seasoning time, rotational speed of the granulator disk: 20 rpm, angle of inclination of the disk: $45^{\circ}$

\section{CONCLUSIONS}

The presented results allow to formulate the following conclusions:

- Increasing the hardener amount from 0.3-0.8 parts by mass in the moulding sand with the investigated resin U404, at a constant resin addition, causes the strength increase after 24 hours of hardening.

- Increasing the resin content in the moulding sand up to 1.2 parts by mass, at a constant hardener addition, causes the strength increase of the investigated moulding sand.

- As far as the reclamation time increases the decrease of $d_{L}$ value occurs. When the reclamation is carried out with the rotational speed of $460 \mathrm{rot} / \mathrm{min}$ the average diameter $d_{L}$ decrease is insignificant, and can be the most clearly seen at position $1\left(\alpha=0^{\circ}\right)$ of the reclaimer.

- Prolongation of the reclamation time caused the theoretical surface increase. The most pronounced growth is observed at the device vessel inclination position 3, i.e. at $\alpha=6^{\circ}$ (app. 8\%).

- Ignition losses of the reclaimed materials (after the mechanical reclamation process) decrease as the reclamation time increases. After 20 minutes the ignition loss retain approximately $55 \%$ of its initial value (losses $45 \%$ ). 
- The obtained results indicate that the applied granulator allows obtaining granules from after the reclamation dusts originated from the spent foundry sands with furan resin and with addition of $50 \%$ of dusts from the bentonite moulding sands reclamation station.

- For the granulator inclination angle being $45^{\circ}$ the best rotational speed of the bowl should be $20 \mathrm{rot} / \mathrm{min}$. At this speed granules are characterised by the highest shatter test resistance, above $90 \%$ - after three days of seasoning.

\section{Acknowledgements}

The study was performed within the 'Dean's Grant' 2012 No. 15.11.170.417.

\section{REFERENCES}

[1] Dańko J., Holtzer M. (eds): Możliwości ograniczenia i metody zagospodarowania odpadów z procesów odlewniczych, Wydawnictwo Naukowe Akapit, Kraków, 2009

[2] Lewandowski J.L.: Tworzywa na formy odlewnicze, Wydawnictwo Akapit, Kraków, 1997

[3] Dańko J., Dańko R., Lucarz M.: Procesy i urządzenia do regeneracji osnowy zużytych mas formierskich, Wydawnictwo Akapit, Kraków, 2007

[4] Holtzer M., Drożyński D., Bobrowski A., Mazur M., Isendorf B.: Ocena wpływu regeneratu na właściwości mas z żywicą furanową, Archives of Foundry Engineering, 10 (2010) 2, 61-64

[5] Dańko J., Holtzer M., Dańko R.: Problems concerning reclamation of used foundry sands, Polish Journal of Environmental Studia, 16 (2007) 3B, 93-96

[6] Holtzer M.: Kierunki rozwoju mas formierskich i rdzeniowych ze spoiwami organicznymi, Archives of Foundry, 3 (2003) 9, 189-196; Archiwum Odlewnictwa, 3 (2003) 9, 189-196

[7] Dańko R.: Innovative developments in sand reclamation technologies, Metalurgija - Metallurgy, 50 (2011) 2 , 93-96

[8] Dańko R., Holtzer M.: Moulding sands grain size investigations by means of the laser method of measurement, Archives of Metallurgy and Materials, 55 (2010) 3, 787-794

[9] Dańko R., Holtzer M., Dańko J.: Reclamation of alkaline spent moulding sands of organic and inorganic type and their mixtures, Archives of Foundry Engineering, 11 (2011) 4, 25-30

[10] Dańko R.: Analysis of effectiveness of used sands reclamation treatment - in various technological devices, Archives of Foundry Engineering, 9 (2009) 4, 31-36

[11] Kamińska J., Skrzyńki M.: Physical, chemical and strength properties of dust from the bentonite sands treatment plants, Metallurgy and Foundry Engineering, 37 (2010) 2, 189-195

[12] Kamińska J.: AGH - Wydz. Odlewnictwa, Kraków, 2011, Dean’s Grant' No 15.11.170.417

Received

November 2012 